\title{
Net anthropogenic phosphorus inputs (NAPI) index application in Mainland China
}

\author{
Yuguo Han ${ }^{\mathrm{a}, *}$, Xinxiao $\mathrm{Yu}^{\mathrm{a}}$, Xiaoxue Wang ${ }^{\mathrm{b}}$, Yunqi Wang ${ }^{\mathrm{a}}$, Jinxia Tian ${ }^{\mathrm{c}}$, Lei Xu ${ }^{\mathrm{d}}$, Chengzhi Wang ${ }^{\mathrm{e}}$ \\ a School of Soil and Water Conservation, Beijing Forestry University, Beijing 100083, China \\ ${ }^{\mathrm{b}}$ State Key Laboratory of Urban and Regional Ecology, Research Center for Eco-Environmental Sciences, Chinese Academy of Sciences, Beijing 100085, China \\ ${ }^{\mathrm{c}}$ Beijing Water Technology Center, Beijing 100073, China \\ ${ }^{\mathrm{d}}$ China Irrigation and Drainage Development Center, Beijing 100054, China \\ ${ }^{\mathrm{e}}$ Water Service Bureau of Chaoyang of Beijing, Beijing 100026, China
}

\section{H I G H L I G H T S}

- We studied phosphorus input more reasonable by taking seeding P into consideration.

- We analyzed spatial and temporal variation of phosphorus input in Mainland China.

- We analyzed the main components of net $\mathrm{P}$ input and their change.

- Fertilize phosphorus is the largest source of net anthropogenic phosphorus input.

- The primary factor of net anthropogenic phosphorus input change is total population.

\section{A R T I C L E I N F O}

\section{Article history:}

Received 8 April 2012

Received in revised form 11 July 2012

Accepted 17 July 2012

Available online 11 August 2012

\section{Keywords:}

NAPI

Mainland China

Historical changes

Socioeconomic factors

\begin{abstract}
A B S T R A C T
This study provides a new understanding on sources of $\mathrm{P}$, which may serve as a foundation for further exploration of anthropogenic effects on $\mathrm{P}$ input. Estimation of net anthropogenic phosphorus input (NAPI) was based on an inventory of phosphorus (P) fertilizer use, consumption of human food and animal feed, seeding phosphorus and non-food phosphorus net flux. Across Mainland China, NAPI had an upward trend from 1981 to 2009, which reflects development trend of the population and economic. NAPI for years 1981, 1990, 2000 and 2009 are $190 \mathrm{~kg} \mathrm{Pm}^{-2} \mathrm{yr}^{-1}\left(1.8 \mathrm{~kg} \mathrm{P}\right.$ per person $\left.\mathrm{yr}^{-1}\right)$, $295 \mathrm{~kg} \mathrm{Pm}^{-2} \mathrm{yr}^{-1}\left(2.5 \mathrm{~kg} \mathrm{P}\right.$ per person $\left.\mathrm{yr}^{-1}\right), 415 \mathrm{~kg} \mathrm{P} \mathrm{km}^{-2} \mathrm{yr}^{-1}\left(3.1 \mathrm{~kg} \mathrm{P}\right.$ per person $\left.\mathrm{yr}^{-1}\right)$ and $465 \mathrm{~kg} \mathrm{P} \mathrm{km}^{-2} \mathrm{yr}^{-1}\left(3.4 \mathrm{~kg}\right.$ P per person $\left.\mathrm{yr}^{-1}\right)$, respectively. On a geographical basis, NAPI per unit area is lower in northwest Mainland China than in southeast Mainland China with the largest NAPI of $3101 \mathrm{~kg} \mathrm{P} \mathrm{km}^{-2} \mathrm{yr}^{-1}$ in Shanghai, while NAPI per person is in reverse with the largest NAPI $7.7 \mathrm{~kg} P$ per person $\mathrm{yr}^{-1}$ in Tibet. P input of fertilizer is the largest source of NAPI, accounting for $57.35-83.73 \%$ (109-390 kg P km${ }^{-2} \mathrm{yr}^{-1}$ ) of the total NAPI, followed by non-food P and P in human food and animal feed. Year 2000 was a critical point where P changed almost from net input to output. Grain production rate per unit mass of fertilizer showed an obvious downward trend. The primary factor in relation to the change in NAPI is total population.
\end{abstract}

(c) 2012 Elsevier Ltd. All rights reserved.

\section{Introduction}

Regional nutrient pollution is divided into point source pollution and non-point source pollution. Point source pollution is generated from sewage outlets, so it is relatively easy to identify and control. Non-point source pollution has complicate formation process, spatial variability, long latent cycle, and so on (Straalen and Gestel, 2008), and its severity is being gradually revealed in re-

\footnotetext{
* Corresponding author. Address: School of Soil and Water Conservation, Beijing Forestry University, 35 Qinghua Donglu, Handian District, P.O. Box 65, Beijing 100083, China. Tel./fax: +861062336324.

E-mail address: yghan@bjfu.edu.cn (Y. Han).
}

cently years. China is one of the countries in the world with rapidest population and economy growth. In the past thirty years, population and economy growth has brought about many environmental issues (Hu et al., 2011a, 2011b; Wu et al., 2011), among which the nutrient non-point source pollution is a relatively serious one. Even though some technology has been used to control nutrient non-point source pollution, the effect is imperceptible because the control actions have been merely focused on end-control engineering projects, such as establishment of sewage farm, artificially-reclaiming of wetland at bayou or watercourse (Liu et al., 2010; Guan et al., 2011). Therefore, investigation on pollutant sources and implementation of source-control policies is indispensable. 
Eutrophication is a kind of water pollution caused by excessive nutrients. Phosphorus $(\mathrm{P})$ is one of the main pollution elements of eutrophication. $\mathrm{P}$ emission from different pathways and sources is a key issue concerning the protection of water quality and sustainable watershed management practices (Lowrance et al., 1985; Rivera et al., 2007; Neset et al., 2008).

The nutrient input to the watershed is mainly caused by human activities (Leeben et al., 2008), such as crop cultivation, livestock breeding, human excretion, household garbage and so on. Many researchers have focused their attention on the evaluation of pollutant loadings by human activities. Jordan and Weller (1996) put forth the concept of net anthropogenic nitrogen input (NANI), which refers to the difference between the total amount of $\mathrm{N}$ produced from applied fertilizer, $\mathrm{N}$ fixation and atmospheric deposition and the total amount of $\mathrm{N}$ exported from food and feed in the watershed ecosystem. The study of McIsaac et al. (2001) shows that NANI is more sensitive to the $\mathrm{N}$ flux in the watershed, i.e. a slight change in NANI may result in a great change in riverine $\mathrm{N}$ content. Russell et al. (2008) also conducted a relevant investigation on net anthropogenic phosphorus input (NAPI $=$ P Fertilizer $+\mathrm{P}$ Feed + P Food + Non-food P), pointing out that NAPI is an important index for predicting the $\mathrm{P}$ pollution in watershed. The theories provide useful research methods for investigation on nutrient input (Bristow et al., 2008; Kelderman et al., 2009; Li et al., 2011; Obour et al., 2011; Han et al., 2011). In addition, nutrient element in seed is always mentioned in researches on agricultural nutrient balance, but it is seldom taken into consideration in NAPI research (OECD, 2001; Feng and Fang, 2006; Fang et al., 2007). Therefore, we introduced a comparatively reasonable way of studying $P$ input by taking $\mathrm{P}$ in seed into consideration, that is, NAPI $=\mathrm{P}$ fertilizer use $+\mathrm{P}$ in seed $+\mathrm{P}$ in human food and animal feed + non-food $\mathrm{P}$.

The purpose of this paper is to calculate net anthropogenic phosphorus budgets in Mainland China, which includes: (a) researching the spatial distribution and temporal variation of net $\mathrm{P}$ input; (b) analyzing the main components of net $\mathrm{P}$ input and their change; and (c) discussing the relationship between the typical socioeconomic factors and net $\mathrm{P}$ input. To some extent, this paper overcomes the difficulties in quantifying $P$ sources and introduces a more reasonable way for studying $\mathrm{P}$ input.

\section{Methods}

\subsection{Study sites}

China is the fourth largest country in the world (after Russia, Canada, and the USA). It is situated at $4^{\circ}$ to $53^{\circ} 30^{\prime}$ North Latitude and $73^{\circ} 40^{\prime}$ to $135^{\circ} 05^{\prime}$ East Longitude and is bordered by Russia, India, Afghanistan, Bhutan, Myanmar, Kazakhstan, North Korea, Kyrgyzstan, Laos, Macau (semi-autonomous), Mongolia, Nepal, Pakistan, Tajikistan, and Vietnam. China covers about $9.6 \times$ $10^{6}$ square $\mathrm{km}$. The population of China is about $13.7 \times 10^{8}$ (as of December, 2010). With highlands in the west and plains in the east, from the Tibetan Plateau and other less-elevated highlands rise rugged east-west trending mountains, and plateaus interrupted by deep depressions fanning out to the north and east. China is composed of 23 provinces, 5 autonomous regions, 4 municipalities, and 2 special administrative regions. The study region in this paper is Mainland China, namely, Taiwan province, Hongkong and Macao special administrative regions are excluded. Therefore, with each administrative region as a research unit, there are 31 research units in total (see Fig. 1 and Table 1 ).

We obtained the data from the National Bureau of Statistics of China. Land cover was derived from satellite images of Ministry of Land and Resources of the People's Republic of China. We calculated net P input values for years 1981, 1990, 2000 and 2009.

\subsection{NAPI estimation approach}

NAPI was estimated by accounting for the anthropogenic P input in each unit. We quantified input of $P$ in each unit, most of which are derived from human activities: fertilizer use, seeding, human food and animal feed, and non-food P.

\subsection{1. $P$ fertilizer use}

Current management practices in agricultural production are highly dependent on intensive fertilizer use, so fertilizer use is one of the important sources of NAPI. We obtained data on the amount of applied $P$ fertilizer within each research unit from the National Bureau of Statistics of China. Estimates of fertilizer application are available for each research unit. P fertilizer contains $12 \%$ $-18 \%$ of $\mathrm{P}_{2} \mathrm{O}_{5}$ (Liang, 1999; Gao et al., 2001). Total P fertilizer application was converted to $\mathrm{kg} P$ by multiplying by $436.4 \mathrm{~kg}$ P per ton $\mathrm{P}_{2} \mathrm{O}_{5}$.

\subsubsection{Seeding $P$}

We chose vegetable and seven main agricultural crops to estimate seeding $P$ in each research unit. The vegetable was represented by cabbage since the value of seeding $\mathrm{P}$ was slightly different between different kinds of vegetable. Seeding $P$ per unit area for each crop type has been reported by Agricultural Technology Promotion Center of China (1999) (see Table 2). The data on cultivation area of each crop type were obtained from the National Bureau of Statistics of China. Seeding P was estimated by multiplying $\mathrm{P}$ input of seed per unit area for each crop type by cultivation area in each research unit.

\subsubsection{Net $P$ input in human food and animal feed}

Humans and animals require a great deal of food and feed during their lives, so net $\mathrm{P}$ in human food and animal feed is also an important component of NAPI. Human food and animal feed are associated with input/output $\mathrm{P}$ of agricultural products. With a few exceptions, we used the general method introduced by Jordan and Weller (1996), who quantified the net input of $P$ as:

net input in food and feed = food and feed consumption of human and animal - animal production for human consumption - crop production.

We obtained data on human population and crop and animal production from the National Bureau of Statistics of China. Each item, as well as the final result, in this method is presented by research unit data.

2.2.3.1. Food and feed consumption. Human consumption of $\mathrm{P}$ in food was estimated by multiplying the number of inhabitants in each research unit (see Table 2) by per capita intake of $0.52 \mathrm{~kg} P$ per year ( $\mathrm{Wu}, 2005)$. P consumption per individual animal was then multiplied by the number of each animal type in each research unit. We chose the values of consumption as reported by Wu Shuxia (2005) and the values of the percentage P excreted as reported by van (1998). We assumed all animals were completely formula fed, i.e., $80 \%$ from corn and $20 \%$ from pasture (Li, 2007).

2.2.3.2. Crop production. We chose vegetable and 14 main agricultural crops to estimate P production in each research unit. The vegetable was represented by cabbage since phosphorus content was slightly different between different kinds of vegetable. We calculated $\mathrm{P}$ content in the crop harvest in each research unit. P content $\left(\mathrm{g} \mathrm{kg}^{-1}\right)$ for each crop type has been reported by Wang (2003) (see Table 2). We assumed that pests, spoilage, and processing caused a $10 \%$ loss for all crops (Jordan and Weller, 1996). 


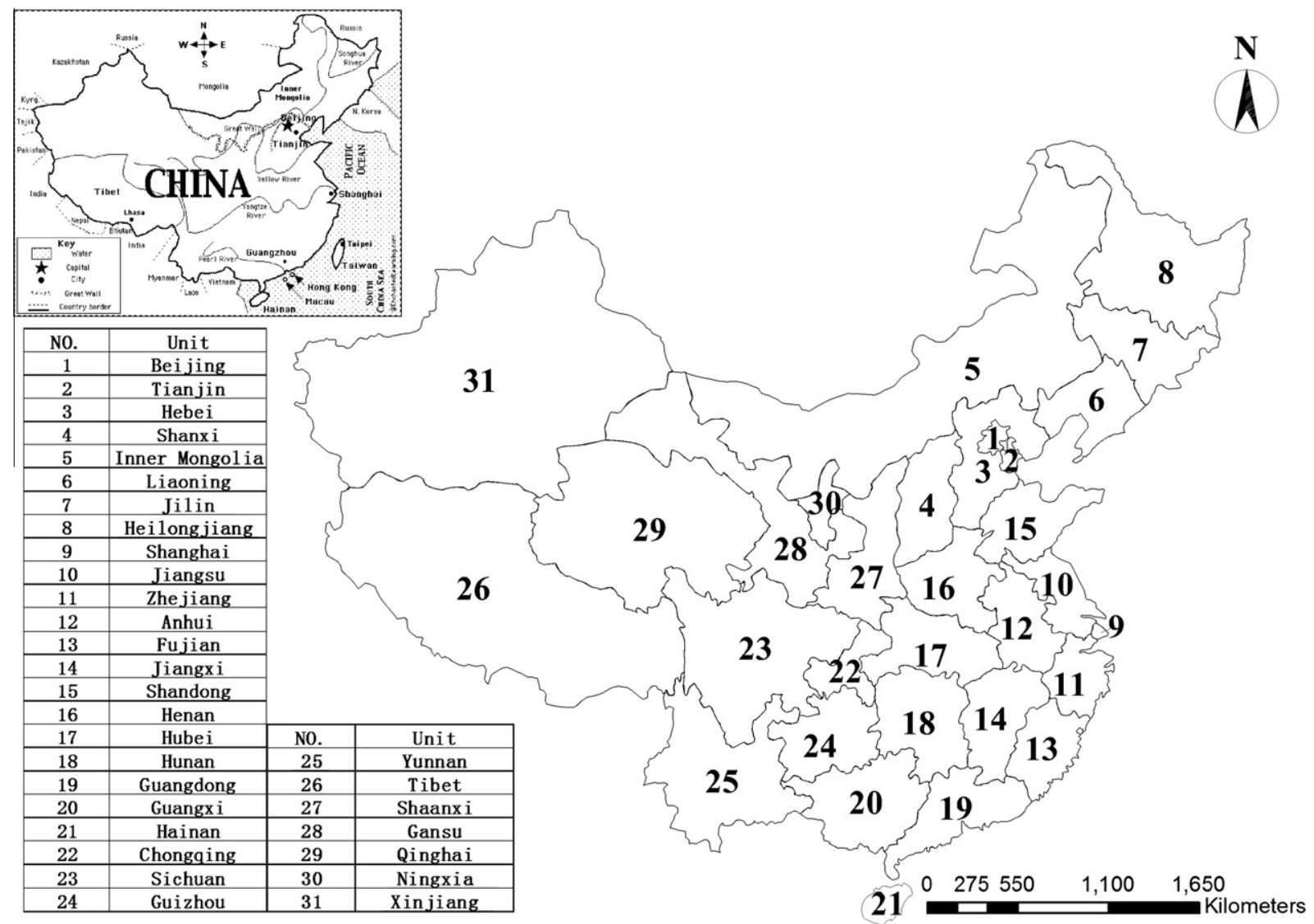

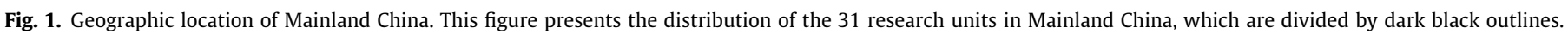

2.2.3.3. Animal production. The animal $\mathrm{P}$ production category includes meat, milk, eggs, etc. We estimated animal P production as the difference between animal feed consumption (intake) and animal excretion (waste production). We assumed that spoilage and inedible components caused a $10 \%$ loss of animal products available for consumption.

\subsubsection{Non-food $P$}

Non-food P mainly comes from the detergent in people's daily life. In China, the sewerage emission is $150 \mathrm{~L}$ per person per day (Shang, 2009; Zhang, 2010). As Shang (2009) measured, concentration of the total $\mathrm{P}$ in Mainland China household sewage was $21 \mathrm{mg} \mathrm{L}^{-1}$. There are $365 \mathrm{~d}$ in 1 year, so the $\mathrm{P}$ discharged from household sewage is $1.15 \mathrm{~kg}$ per person per year. As P discharged from human excretion was $0.52 \mathrm{~kg}$ per person per year, the rest $\mathrm{P}$, i.e., non-food $\mathrm{P}$ was $0.63 \mathrm{~kg}$ per person per year.

\subsection{Data analysis}

\subsubsection{Analysis of NAPI}

Based on P fertilizer use, P in human food and animal feed, seeding $P$ and non-food P, NAPI was calculated by summing the values for all research units within Mainland China. Geographic and spatial analysis of NAPI was conducted using average NAPI values in the 31 research units for years 1981, 1990, 2000 and 2009. The land cover data was used with the ArcInfo 9.3 (ESRI Inc.) geographic information system to calculate the proportion of row crops and forest in each unit, while the number of animal in each unit was calculated from agricultural census data. We also investigated differences in NAPI and in its components between different years.

\subsubsection{Grey relational analysis}

Gray System Theory (GST) gradually developed from requirements for new methods to solve certain problems for solving the complicated interrelationships among the multiple performance characteristics (Deng, 1989). Grey Relational Analysis (GRA) is one of GST. GRA uses the gray relational coefficient (GRC) to describe the trend relationship between an objective series and a reference series at a given point in a system. For a given reference sequence and a given set of comparative sequences, GRA can be used to determine the gray relational grade (GRG) between the reference and each comparative sequence in the given set. Grey relational generating is a process of transferring the original sequence to a comparable sequence. For this purpose, the experimental results are normalized in the range between zero and one (Lin, 2004).

Grey relational grade analysis was conducted between the socioeconomic factors (gross domestic product, gross agricultural output value, cultivated land area, total population density, agricultural population density, the total fertilizer, total population and total grain yield) and NAPI calculation in this paper. GRA was analyzed with the GM v2.1 (Nanjing University of Aeronautics and Astronautics).

\section{Results}

\subsection{Spatial variation of NAPI}

The geographic differences of NAPI average for years 1981, 1990, 2000 and 2009 in Mainland China was investigated (see Fig. 2). NAPI per unit area is lower in northwest Mainland China than in southeast Mainland China (see Fig. 2a) and NAPI per person exactly reverses NAPI per unit area (see Fig. 2b) since NAPI is in 
Table 1

Characteristics of Mainland China.

\begin{tabular}{|c|c|c|c|c|c|}
\hline \multirow[t]{2}{*}{ Name } & \multirow[t]{2}{*}{ Area $\left(10^{4} \mathrm{~km}^{2}\right)$} & \multicolumn{4}{|c|}{ Population $\left(10^{4}\right)$} \\
\hline & & 1981 & 1990 & 2000 & 2009 \\
\hline Beijing & 1.68 & 902.00 & 1087.00 & 1382.00 & 1755.00 \\
\hline Tianjin & 1.13 & 763.00 & 883.00 & 1001.00 & 1228.16 \\
\hline Hebei & 19.00 & 5256.00 & 6028.00 & 6744.00 & 7034.40 \\
\hline Shanxi & 15.60 & 2509.00 & 2818.00 & 3297.00 & 3427.36 \\
\hline Inner Mongolia & 118.30 & 1903.00 & 2111.00 & 2376.00 & 2422.07 \\
\hline Liaoning & 14.57 & 3535.00 & 3998.00 & 4238.00 & 4319.00 \\
\hline Jilin & 18.70 & 2231.00 & 2515.00 & 2728.00 & 2739.55 \\
\hline Heilongjiang & 46.90 & 3239.00 & 3477.00 & 3689.00 & 3826.00 \\
\hline Shanghai & 0.62 & 1163.00 & 1351.00 & 1674.00 & 1921.00 \\
\hline Jiangsu & 10.26 & 6010.00 & 6817.00 & 7438.00 & 7725.00 \\
\hline Zhejiang & 10.18 & 3871.00 & 4084.00 & 4677.00 & 5180.00 \\
\hline Anhui & 13.90 & 4956.00 & 5629.00 & 5986.00 & 6131.00 \\
\hline Fujian & 12.00 & 2557.00 & 3061.00 & 3471.00 & 3627.00 \\
\hline Jiangxi & 16.66 & 3304.00 & 3828.00 & 4140.00 & 4432.16 \\
\hline Shandong & 15.30 & 7395.00 & 8343.00 & 9079.00 & 9470.30 \\
\hline Henan & 16.70 & 7397.00 & 8614.00 & 9256.00 & 9487.00 \\
\hline Hubei & 18.74 & 4740.00 & 5476.00 & 6028.00 & 5720.00 \\
\hline Hunan & 21.00 & 5360.00 & 6060.00 & 6440.00 & 6406.00 \\
\hline Guangdong & 18.60 & 5884.00 & 6321.00 & 8642.00 & 9638.00 \\
\hline Guangxi & 23.63 & 3613.00 & 4253.00 & 4489.00 & 4856.00 \\
\hline Hainan & 3.40 & 565.05 & 642.00 & 787.00 & 864.07 \\
\hline Chongqing & 8.20 & 2685.45 & 2878.39 & 3090.00 & 2859.00 \\
\hline Sichuan & 48.80 & 7238.55 & 7758.61 & 8329.00 & 8185.00 \\
\hline Guizhou & 17.00 & 2827.00 & 3273.00 & 3525.00 & 3798.00 \\
\hline Yunnan & 39.40 & 3223.00 & 3675.00 & 4288.00 & 4571.00 \\
\hline Tibet & 122.00 & 186.00 & 222.00 & 262.00 & 290.03 \\
\hline Shaanxi & 20.50 & 2865.00 & 3247.00 & 3605.00 & 3772.00 \\
\hline Gansu & 45.00 & 1941.00 & 2293.00 & 2562.00 & 2635.46 \\
\hline Qinghai & 72.00 & 382.00 & 443.00 & 518.00 & 557.30 \\
\hline Ningxia & 6.64 & 383.00 & 466.00 & 562.00 & 625.20 \\
\hline Xinjiang & 160.00 & 1303.00 & 1537.00 & 1925.00 & 2158.63 \\
\hline
\end{tabular}

This table presents the research units. The area is indicated in ten thousands $\mathrm{km}^{2}$; and the population was collected in 1981, 1990, 2000, 2009 and is indicated in ten thousands.

relation to population density and agriculture land area. Northwest Mainland China is mainly covered by forest and desert (see Fig. 2c), where NAPI per unit area is relatively lower, while southeast Mainland China is mainly covered by agricultural and developed land, where NAPI per unit area is relatively higher. Southeast Mainland China is a region with rapidly developed economy and thus has a greater population density and a higher gross domestic product (GDP). The study areas focusing on cities generally have a greater population density and relatively less agriculture land area. Thus, NAPI per person in these areas is lower. In contrast, the study areas focusing on agriculture have a lower population density and larger agriculture land area. Thus, NAPI per person in these areas is higher. Shanghai has the largest NAPI of $3101 \mathrm{~kg} \mathrm{P} \mathrm{km}^{-2} \mathrm{yr}^{-1}$ (see Fig. 2a), and Tibet has the largest NAPI $7.7 \mathrm{~kg} P$ per person $\mathrm{yr}^{-1}$ (see Fig. 2b). Over the past 28 years, the average NAPI was $341 \mathrm{~kg} \mathrm{P} \mathrm{km}^{-2} \mathrm{yr}^{-1}$ or $2.7 \mathrm{~kg} \mathrm{P}$ per person $\mathrm{yr}^{-1}$ in Mainland China.

\subsection{Temporal variation of NAPI}

NAPI for different years in Mainland China is investigated (see Table 3). Across Mainland China, the largest NAPI value (465 $\mathrm{kg} \mathrm{P} \mathrm{km}^{-2} \mathrm{yr}^{-1}$, $3.4 \mathrm{~kg} \mathrm{P}$ per person $\mathrm{yr}^{-1}$ ) appeared in 2009. Over the past 28 years, NAPI per unit area had an upward trend in the 31 research units, which reflects development trend of population and economic. NAPI per person had an upward trend in most research units except Beijing, Liaoning, Jilin, Shanghai, Tibet and Qinghai. Such difference was mainly caused by NAPI quantity and population. Over the past 28 years, cultivated area of Mainland China increased from $9.9 \times 10^{5} \mathrm{~km}^{2}$ to $12.2 \times 10^{5} \mathrm{~km}^{2}$, while fertilizer use quantity increased from $133 \times 10^{5}$ ton to $539 \times 10^{5}$ ton and meanwhile population increased from $9.9 \times 10^{8}$ to $13.2 \times 10^{8}$. Therefore, NAPI quantity had a rising trend. As for NAPI per unit area, Henan $\left(2675 \mathrm{~kg} \mathrm{P} \mathrm{km}^{-2} \mathrm{yr}^{-1}\right)$ had a greatest change over the last 28 years, followed by Tianjin $\left(1615 \mathrm{~kg} \mathrm{P} \mathrm{km}^{-2} \mathrm{yr}^{-1}\right)$ and Hubei (1402 $\mathrm{kg} \mathrm{P} \mathrm{km}^{-2} \mathrm{yr}^{-1}$ ). As for NAPI per person, Xinjiang $\left(6.5 \mathrm{~kg} \mathrm{P}\right.$ per person $\mathrm{yr}^{-1}$ ) had a greatest change, followed by Henan (4.3 $\mathrm{kg}$ P per person $\mathrm{yr}^{-1}$ ) and Hubei ( $4.3 \mathrm{~kg}$ P per person $\mathrm{yr}^{-1}$ ).

\subsection{Change in NAPI sources}

The sources of NAPI in Mainland China in different years were analyzed (see Fig. 3). P input of fertilizer is the largest source of NAPI, followed by non-food P. P fertilizer use had an upward trend from $57.35 \%\left(109.12 \mathrm{~kg} \mathrm{P} \mathrm{km}^{-2} \mathrm{yr}^{-1}\right)$ to $83.73 \%(389.58 \mathrm{~kg} \mathrm{P}$ $\mathrm{km}^{-2} \mathrm{yr}^{-1}$ ) of NAPI from 1981 to 2009, and meanwhile cultivated area increased only from $9.90 \times 10^{5} \mathrm{~km}^{2}$ to $12.17 \times 10^{5} \mathrm{~km}^{2}$. As can be seen, fertilizer use per unit area had a sharp increase.

Non-food P is closely related to population. Since population has been increasing, non-food $\mathrm{P}$ input increased from $66.02 \mathrm{~kg} \mathrm{P} \mathrm{km}^{-2} \mathrm{yr}^{-1}$ in 1981 to $87.25 \mathrm{~kg} \mathrm{P} \mathrm{km}^{-2} \mathrm{yr}^{-1}$ in 2009.

Table 2

Data and values of NAPI subentry.

\begin{tabular}{|c|c|c|c|c|c|c|c|c|c|c|c|}
\hline \multicolumn{3}{|c|}{ Input of seeding $\mathrm{P}$} & \multicolumn{5}{|c|}{ Animal and human P consumption and excretion (Van, 1998; Wu, 2005) } & \multicolumn{4}{|c|}{$\begin{array}{l}\text { P content in agricultural crop products } \\
\text { (Wang, 2003) }\end{array}$} \\
\hline Seed type & $\begin{array}{l}\text { Seeding } \\
\mathrm{P} \\
\left(\mathrm{g} \mathrm{kg}^{-1}\right)\end{array}$ & $\begin{array}{l}\text { Seeding P } \\
\left(\mathrm{kg} \mathrm{hm}^{-2}\right)\end{array}$ & $\begin{array}{l}\text { Animal } \\
\text { type }\end{array}$ & $\begin{array}{l}\text { Waste production ( } \mathrm{P} \\
\left.\text { excretion, } \mathrm{kg} \mathrm{P}^{-1} \text { individual }^{-1} \mathrm{yr}^{-1}\right)\end{array}$ & $\begin{array}{l}\text { Percent } \\
\text { excreted } \\
(\%)\end{array}$ & $\begin{array}{l}\text { Consumption ( } \mathrm{P} \\
\text { intake rate, } \mathrm{kg} \mathrm{P}^{\mathrm{P}} \\
\text { individual }^{-1} \mathrm{yr}^{-1} \text { ) }\end{array}$ & $\begin{array}{l}\text { Animal } \\
\text { production }(\mathrm{kg} \mathrm{P} \\
\left.\text { individual }^{-1} \mathrm{yr}^{-1}\right)\end{array}$ & Crop type & $\begin{array}{l}\mathrm{P} \\
\left(\mathrm{g} \mathrm{kg}^{-1}\right)\end{array}$ & Crop type & $\begin{array}{l}\mathrm{P} \\
\left(\mathrm{g} \mathrm{kg}^{-1}\right)\end{array}$ \\
\hline Paddy & 1.82 & 6.43 & $\begin{array}{l}\text { Hog } \\
\text { and pig }\end{array}$ & 3.17 & 69 & 4.59 & 1.42 & Corn & 2.44 & Chestnut & 0.89 \\
\hline Wheat & 3.02 & 23.81 & $\begin{array}{l}\text { Horse } \\
\text { and } \\
\text { cattle }\end{array}$ & 9.78 & 89 & 10.99 & 1.21 & Wheat & 1.88 & Apples & 0.12 \\
\hline Corn & 2.54 & 4.53 & Chicken & 0.12 & 65 & 0.18 & 0.06 & Soybeans & 4.65 & Grapes & 0.13 \\
\hline Soybean & 4.91 & 8.90 & Duck & 0.22 & 65 & 0.34 & 0.12 & Paddy & 1.10 & Peaches & 0.14 \\
\hline Broomcorn & 3.29 & 5.96 & $\begin{array}{l}\text { Sheep } \\
\text { and } \\
\text { lamb }\end{array}$ & 1.06 & 84 & 1.26 & 0.20 & Millet & 2.99 & Pears & 0.13 \\
\hline Peanut & 0.32 & 0.58 & Human & 0.52 & 100 & 0.52 & - & Broomcorn & 3.29 & Watermelon & 0.12 \\
\hline Cotton & 0.22 & 0.04 & & & & & & Peanuts & 2.50 & Vegetable & 0.30 \\
\hline Vegetable & 0.34 & 0.03 & & & & & & Potatoes & 0.40 & & \\
\hline
\end{tabular}

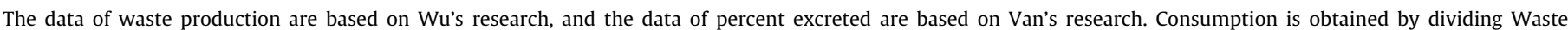
production by Percent excreted, and Animal production is estimated as Consumption minus Waste production. 

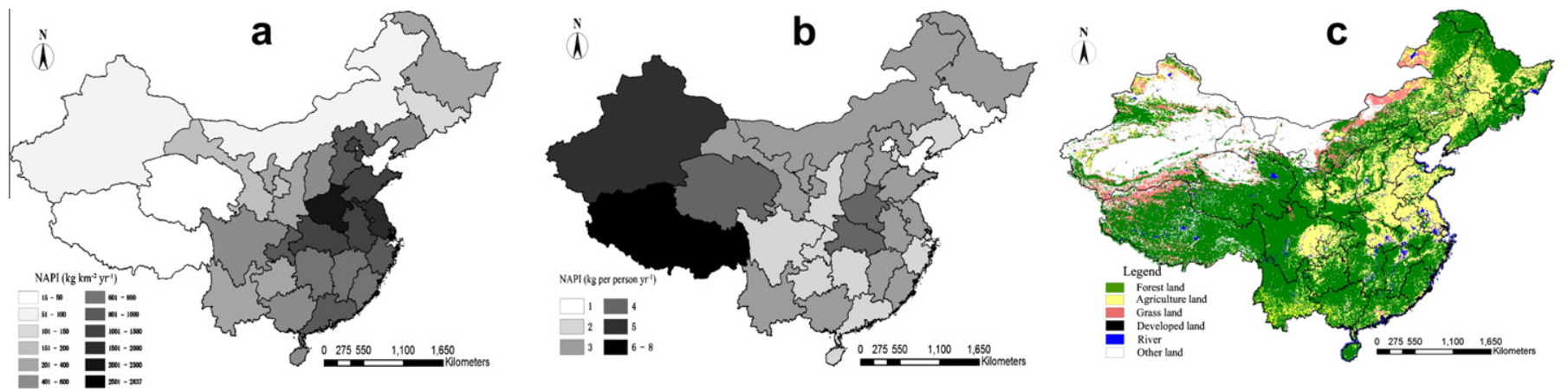

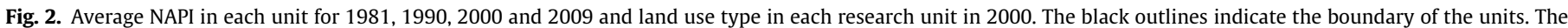
land use is classified as forest land, agriculture land, grass land, developed land, river and other land.

Table 3

NAPI for different years .

\begin{tabular}{|c|c|c|c|c|c|c|c|c|c|c|}
\hline \multirow[t]{2}{*}{ Name } & \multicolumn{5}{|c|}{ NAPI per unit area $\left(\mathrm{kg} \mathrm{P} \mathrm{km}^{-2} \mathrm{yr}^{-1}\right)$} & \multicolumn{5}{|c|}{ NAPI per person ( $\mathrm{kg}^{\mathrm{P}}$ per person $\mathrm{yr}^{-1}$ ) } \\
\hline & 1981 & 1990 & 2000 & 2009 & $\begin{array}{l}\text { Difference between } \\
1981 \text { and } 2009\end{array}$ & 1981 & 1990 & 2000 & 2009 & $\begin{array}{l}\text { Difference between } \\
1981 \text { and } 2009\end{array}$ \\
\hline Beijing & 931 & 717 & 1108 & 1361 & 430 & 1.7 & 1.1 & 1.3 & 1.3 & -0.4 \\
\hline Tianjin & 849 & 824 & 1593 & 2464 & 1615 & 1.3 & 1.1 & 1.9 & 2.4 & 1.1 \\
\hline Hebei & 495 & 794 & 1260 & 1300 & 804 & 1.8 & 2.5 & 3.5 & 3.5 & 1.7 \\
\hline Shanxi & 281 & 505 & 732 & 690 & 409 & 1.8 & 2.8 & 3.5 & 3.2 & 1.4 \\
\hline Inner Mongolia & 32 & 40 & 66 & 119 & 87 & 1.9 & 2.2 & 3.2 & 5.7 & 3.7 \\
\hline Liaoning & 492 & 560 & 569 & 564 & 72 & 2.1 & 2.1 & 2.0 & 1.9 & -0.1 \\
\hline Jilin & 181 & 134 & 170 & 147 & -34 & 1.6 & 1.3 & 1.2 & 1.0 & -0.5 \\
\hline Heilongjiang & 91 & 153 & 273 & 345 & 255 & 1.3 & 2.0 & 3.4 & 4.1 & 2.8 \\
\hline Shanghai & 2950 & 2403 & 2895 & 3101 & 152 & 2.1 & 1.5 & 1.4 & 1.3 & -0.8 \\
\hline Jiangsu & 1210 & 1387 & 2089 & 2439 & 1229 & 2.2 & 2.2 & 3.0 & 3.4 & 1.2 \\
\hline Zhejiang & 714 & 836 & 854 & 972 & 259 & 1.9 & 2.2 & 1.9 & 2.0 & 0.0 \\
\hline Anhui & 615 & 1233 & 1597 & 1411 & 796 & 1.7 & 3.1 & 3.7 & 3.2 & 1.5 \\
\hline Fujian & 399 & 653 & 833 & 909 & 510 & 1.9 & 2.7 & 3.0 & 3.1 & 1.2 \\
\hline Jiangxi & 328 & 635 & 710 & 785 & 457 & 1.7 & 2.8 & 2.9 & 3.0 & 1.3 \\
\hline Shandong & 947 & 1235 & 1928 & 1742 & 796 & 2.0 & 2.3 & 3.3 & 2.9 & 0.9 \\
\hline Henan & 665 & 1678 & 2858 & 3340 & 2675 & 1.5 & 3.2 & 5.1 & 5.8 & 4.3 \\
\hline Hubei & 424 & 912 & 1445 & 1826 & 1402 & 1.7 & 3.1 & 4.5 & 5.9 & 4.3 \\
\hline Hunan & 493 & 636 & 705 & 767 & 274 & 2.0 & 2.2 & 2.3 & 2.5 & 0.6 \\
\hline Guangdong & 653 & 796 & 895 & 1145 & 492 & 2.0 & 2.3 & 1.9 & 2.1 & 0.1 \\
\hline Guangxi & 288 & 458 & 606 & 702 & 414 & 1.9 & 2.6 & 3.2 & 3.4 & 1.5 \\
\hline Hainan & 295 & 442 & 487 & 696 & 401 & 1.9 & 2.4 & 2.2 & 2.9 & 1.0 \\
\hline Chongqing & 512 & 744 & 1063 & 1075 & 564 & 1.6 & 2.1 & 2.8 & 3.1 & 1.5 \\
\hline Sichuan & 242 & 341 & 491 & 570 & 328 & 1.6 & 2.1 & 2.9 & 3.4 & 1.8 \\
\hline Guizhou & 269 & 381 & 441 & 459 & 190 & 1.7 & 2.1 & 2.2 & 2.1 & 0.5 \\
\hline Yunnan & 144 & 241 & 319 & 394 & 250 & 1.7 & 2.5 & 2.9 & 3.3 & 1.6 \\
\hline Tibet & 13 & 14 & 15 & 19 & 6 & 8.3 & 7.6 & 7.0 & 8.0 & -0.3 \\
\hline Shaanxi & 216 & 322 & 491 & 547 & 331 & 1.6 & 2.0 & 2.8 & 3.0 & 1.4 \\
\hline Gansu & 85 & 166 & 268 & 235 & 150 & 1.8 & 2.9 & 4.2 & 3.6 & 1.8 \\
\hline Qinghai & 26 & 31 & 29 & 30 & 3 & 4.9 & 5.1 & 4.1 & 3.8 & -1.1 \\
\hline Ningxia & 145 & 187 & 345 & 421 & 276 & 2.0 & 2.1 & 3.2 & 3.5 & 1.5 \\
\hline Xinjiang & 18 & 31 & 61 & 113 & 95 & 2.3 & 3.4 & 5.3 & 8.7 & 6.5 \\
\hline Mainland China & 190 & 295 & 415 & 465 & 275 & 1.8 & 2.5 & 3.1 & 3.4 & 1.5 \\
\hline
\end{tabular}

However, its percentage to the total input decreased (from $34.69 \%$ to $18.75 \%$ ) mainly due to more rapid increase of NAPI.

Net $\mathrm{P}$ in human food and animal feed is proportional to the human population and animal numbers. The positive percentage values of $\mathrm{P}$ for human food and animal feed indicate that $\mathrm{P}$ input occurs, while the negative percentage values indicate the possible occurrence of $\mathrm{P}$ output (see Fig. 3). When dietary demands for $\mathrm{P}$ cannot be met by local crop and animal product, it is necessary to import food and feed; otherwise, export of food and feed may be needed. Year 2000 was a critical point where $P$ changed almost from net input to output, indicating that food product could almost satisfy people's demands since then. Over the past 28 years, $\mathrm{P}$ in human food and animal feed had a downward trend (from $7.48 \%$ to $2.76 \%$ ).
Seeding $\mathrm{P}$ is closely related to cultivated area, so seeding $\mathrm{P}$ input increased from $0.91 \mathrm{~kg} \mathrm{P} \mathrm{km}^{-2} \mathrm{yr}^{-1}$ in 1981 to $1.27 \mathrm{~kg} \mathrm{P} \mathrm{km}^{-2} \mathrm{yr}^{-1}$ in 2009. However, its percentage to the total input decreased (from $0.48 \%$ to $0.27 \%$ ) mainly due to more rapid increase of NAPI.

\section{Discussion}

\subsection{Relational analysis between the socioeconomic factors and NAPI}

Grey relational grade analysis was conducted between the socoeconomic factors (gross domestic product, gross agricultural output value, cultivated land area, total population density, agricultural population density, total fertilizer, total population 

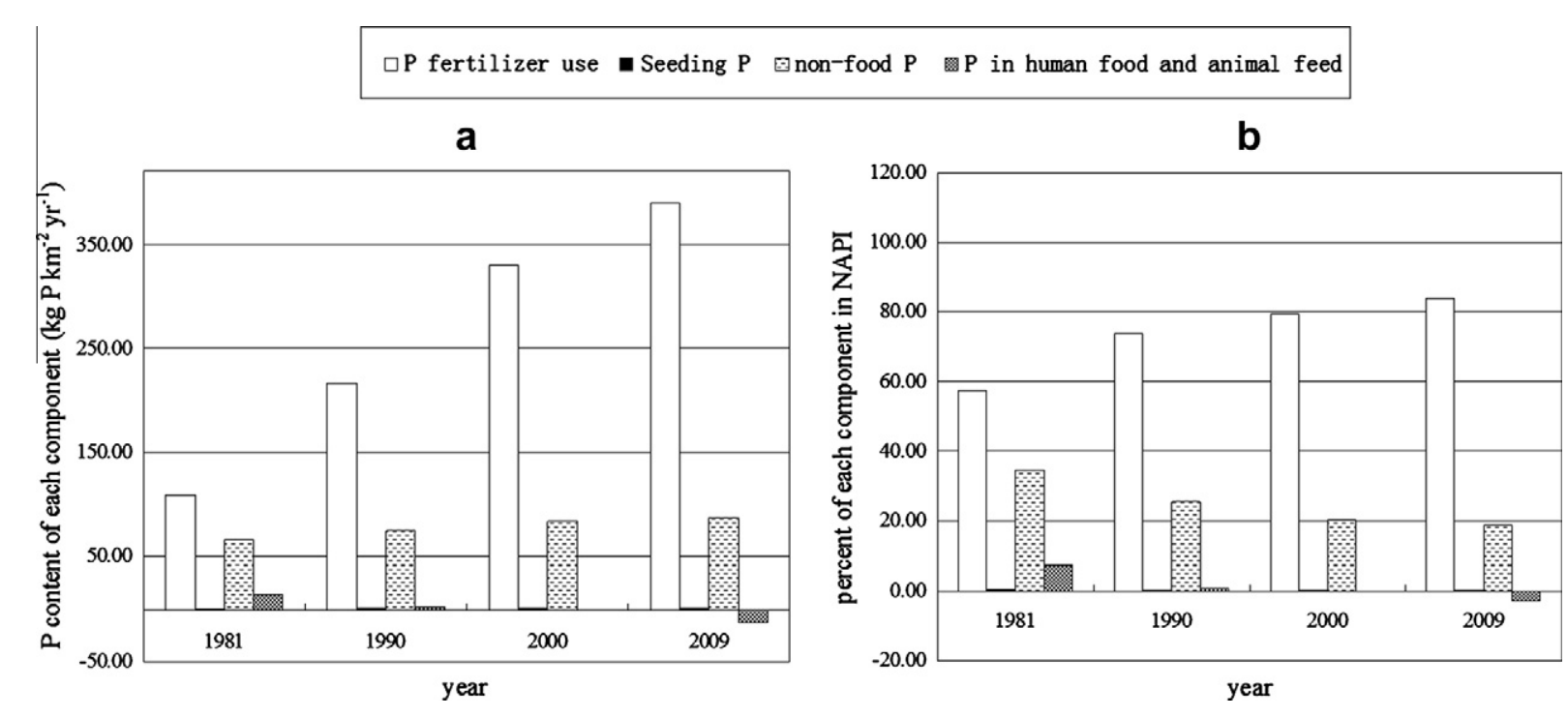

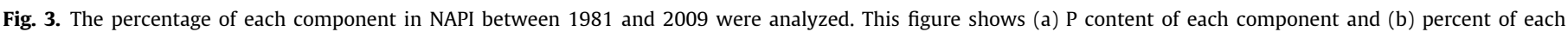
component in NAPI.

and total grain yield) and NAPI calculation with a discrimination coefficient $(\rho)$ of 0.5 . The results are as follows (see Table 4):

$X_{7}>X_{4}>X_{3}>X_{9}>X_{5}>X_{6}>X_{1}>X_{2}>X_{8}$

The primary factor in relation to the change in NAPI is total population, followed by population density and cultivated land area. Among all of the factors, total population density, agricultural population density and total population are main social factors and their relational grades are $0.992,0.975$ and 0.999 , respectively. Total population density has the greatest relational grade, indicating that change in NAPI is mainly determined by the total population density. Cultivated land area, total fertilizer and total grain yield are main agricultural factors and their relational grades are $0.985,0.972$ and 0.982 , respectively. As can be seen, cultivated land area has the greatest relational grade, indicating that among the agricultural factors, cultivated land area is a main factor in relation to the change in NAPI. Gross Domestic Product and Gross Agricultural Output Value are main economic factors and their relational grades are 0.897 and 0.839 , respectively. Gross Domestic Product has the greatest relational grade, so Gross Domestic Product is the closest economic factor in relation to NAPI change in this study.

\subsection{Grain production rate}

World-wide agricultural development has proved that fertilizer application is the fastest, most effective and most important means for increasing production. China is an intensive-agriculture country, and agricultural production is highly dependent on fertilizer application (Li et al., 1998; Chen et al., 2007). The cultivated land area in China is $1 / 7$ of the total in the world, but its fertilizer application accounts for $1 / 3$ of the total in the world, ranking first in the world (Chen et al., 2011; Huang et al., 2011; Zhou et al., 2012). In this study, the total grain yield in 2009 was 1.62 times in 1981, while the amount of fertilizer applied was 4.04 times (see Table 4). Grain production rate per unit mass of fertilizer showed an obvious downward trend, indicating that the amount of applied fertilizer per unit weight of grain was gradually increasing, i.e., the fertilizer utilization efficiency was gradually reducing. Low fertilizer utilization efficiency may decline soil fertility, drop crop quality and cause serious environmental pollution (Schroder et al., 2011; Chien et al., 2011). Therefore, it is significant for China to improve fertilizer utilization efficiency in agriculture.

\subsection{Method for improving fertilizer utilization efficiency}

China is facing harsh problems of growing population, shrinking arable land and increasing food demand. Maximization of fertilizer utilization efficiency is extremely important for food security and ecological environment protection ( $\mathrm{Hu}$ and $\mathrm{Li}, 2005$; Yan et al., 2008). At present, the main techniques and methods are: 1 . Fertilizing accurately in accordance with the farmland nutrients and promoting formulated fertilization technology, that is, based on the rule of fertilizer requirement of crops, soil testing results and fertilizer utilization efficiency, the amount of fertilizer to be applied is adjusted to be reasonable, so that the crops are supplied with comprehensive and reasonable nutrients so as to maximize the potential of crops in increasing yield, thereby improving economic efficiency (Peng et al., 1996, 2002; Gao and Lü, 2006; Liu et al., 2006; He et al., 2007); 2. Developing slow/release fertilizers; slow/release fertilizers can slowly release nutrients necessary for plant growth; they are rich in nutrients, formulated reasonably, pollution-free and long-term effective, and may reduce nutrient loss caused by leaching, fixation or decomposition so as to prevent the crops from premature aging at early stage and de-fertilization at later stage; the nutrients are released no less than $75 \%$ within the provided release period; therefore, slow/release fertilizers are considered as the most efficient and convenient measure for reducing fertilizer losses and improving fertilizer utilization efficiency (Zhai et al., 2002; Du et al., 2005); and 3. Improving methods of fertilizing; according to the rule of fertilizer requirement of crops, crops are fertilized reasonably in various growth stages to satisfy the demand for nutrient at each stage so as to achieve the purpose of economic fertilization (Wang, 2002; Lu and Wu, 2004; Jess, 2004; Yu and Zhang, 2006); deep application of fertilizer also needs to be promoted to minimize the loss of fertilizer and improve fertilizer utilization efficiency.

\subsection{Fate of NAPI}

From the above analysis we can see that there is a huge amount of $\mathrm{P}$ input in Mainland China every year. But, where has it gone? Part of it has been deposited in the plant and animal, which is an important mode of $P$ input. Animal and plant cannot survive without $\mathrm{P}$ as $\mathrm{P}$ is an important component of animal's nucleic acid of genetic material and is involved in plant's photosynthesis and 
respiration. Part of it has been deposited in the soil. A lot of fertilizer is applied into soil, no more than $50 \%$ of which are absorbed by plant (Wang et al., 2010) and the rest of which flows into rivers because of erosion (Barbosa et al., 2009; Stevens et al., 2009; Kerr et al., 2011; Kronvang et al., 2012) or is deposited in the soil. The other part $\mathrm{P}$ in human excretion flows through sewers into rivers. $\mathrm{P}$ input in the groundwater and rivers leads to eutrophication of water, which results in that the water loses its ecological functions, thereby leading to the serious environmental problems such as eutrofication, anoxia or cyanobacteria developpement (Istvanovics et al., 2002; Antoniades et al., 2011; Hu et al., 2011a, 2011b; Tugrul et al., 2011).

By the end of $2009,53.2 \%$ of household sewage in Mainland China was treated by sewage treatment plant (Zhou, 2010). After the treatment, 90\% of sewage P was left in the sludge of the sewage treatment plant and would eventually be landfilled. In recent years, researches on re-use of sewage sludge are being conducted (e.g., used as agricultural fertilizer and the production of biogas, etc.), but currently they have not been applied on a large scale (Xiong and Zhang, 2007).

\subsubsection{To control the sources of $P$ pollution}

First of all, a reasonable region planning is needed, which may play an obvious role in regulating and controlling $P$ pollution from the perspective of population. As for a reasonable region planning, such as the reasonable population distribution and public transportation system, the key point is to change the existed intensive work and life style, which, however, needs a long time. Secondly, scientific fertilizer application, especially the use of organic fertilizer should be emphasized. The amount, manner and time of the organic fertilizer application should be based on the soil properties, crop growing conditions, properties of the crop in absorbing the nutrition (Liu et al., 2010). Thirdly, the disposal of agricultural wastes such as livestock manure and crop straw should be regulated. P pollution caused by directly abandoned agricultural wastes cannot be ignored as they are rich in organic matter and nutrients. A biological waste management and centralized livestock management should be adopted to prevent $P$ loss in the agricultural surface water. In addition, crop residue and straw play an important practical role in controlling soil erosion, inhibiting nutrient loss and preventing $\mathrm{P}$ pollution.

\subsubsection{To control $P$ diffusion}

Currently, P diffusion can be effectively controlled by means of ecological engineering. Generally, $P$ diffusion is controlled by inhibiting runoff and increasing infiltration. Many countries are developing a buffer zone to control P pollution, e.g., the vegetative filter zone in the United States and the buffer region in the Briton. After years of experimental studies (Fu et al., 2006), Chengqing Yin has found that multiple-ponds method may prevent up to $94 \%$ of $\mathrm{P}$ pollution. P pollution can also be effectively controlled by means of combination of engineering measures, biological measures with water and soil conservation through building sand-sinking pool, percolation pond, water catchments and water treatment facility.

\section{Conclusion}

This study took a step forward to calculate NAPI in detail on a regional scale, and analyzed its temporal variations and geographic differences. Across Mainland China, NAPI for years 1981, 1990, 2000 and 2009 are $190 \mathrm{~kg} \mathrm{P} \mathrm{km}^{-2} \mathrm{yr}^{-1}\left(1.8 \mathrm{~kg} \mathrm{P}\right.$ per person $\left.\mathrm{yr}^{-1}\right)$, $295 \mathrm{~kg} \mathrm{P} \mathrm{km}^{-2} \mathrm{yr}^{-1}\left(2.5 \mathrm{~kg} \mathrm{P}\right.$ per person $\left.\mathrm{yr}^{-1}\right), 415 \mathrm{~kg} \mathrm{P} \mathrm{km}^{-2}$ $\mathrm{yr}^{-1}\left(3.1 \mathrm{~kg} \mathrm{P}\right.$ per person $\left.\mathrm{yr}^{-1}\right)$ and $465 \mathrm{~kg} \mathrm{P} \mathrm{km}^{-2} \mathrm{yr}^{-1}(3.4 \mathrm{~kg} \mathrm{P}$ per person $\left.\mathrm{yr}^{-1}\right)$, respectively. On a geographical basis, NAPI per unit area is lower in northwest Mainland China than in southeast 
Mainland China with the largest NAPI of $3101 \mathrm{~kg} \mathrm{P} \mathrm{km}^{-2} \mathrm{yr}^{-1}$ in Shanghai, while NAPI per person is in reverse with the largest NAPI $7.7 \mathrm{~kg} P$ per person $\mathrm{yr}^{-1}$ in Tibet. $\mathrm{P}$ input of fertilizer is the largest source of NAPI, accounting for $57.35-83.73 \%(109-390 \mathrm{~kg} \mathrm{P}$ $\mathrm{km}^{-2} \mathrm{yr}^{-1}$ ) of the total NAPI, followed by non-food $\mathrm{P}$ and $\mathrm{P}$ in human food and animal feed. Over the past 28 years, all of the sources of NAPI showed an upward trend. The primary factor in relation to the change in NAPI is total population, followed by population density and cultivated land area. In summary, this study provides a new understanding of sources of $P$ in Mainland China, which may serve as a foundation for further exploration of anthropogenic effects on $\mathrm{P}$ input.

\section{Acknowledgment}

Funding for this work was supported by the Fundamental Research Funds for the Central Universities (No. TD2011-01), and supported by CFERN \& GENE Award Funds on Ecological Paper.

\section{References}

Agricultural Technology Promotion Center of China, 1999. Organic Fertilizer Nutrient of China, Ed.. China Agriculture Press, Beijing, China.

Antoniades, D., Michelutti, N., Quinlan, R., 2011. Cultural eutrophication, anoxia, and ecosystem recovery in Meretta Lake, High Arctic Canada. Limnol. Oceanogr. 56, 639-650.

Barbosa, F.T., Bertol, I., Luciano, R.V., 2009. Phosphorus losses in water and sediments in runoff of the water erosion in oat and vetch crops seed in contour and downhill. Soil. Till. Res. 106, 22-28.

Bristow, C.E., Morin, A., Hesslein, R.H., 2008. Phosphorus budget and productivity of an experimental lake during the initial three years of cage aquaculture. Can. J. Fish Aquat. Sci. 65, 2485-2495.

Chen, T.B., Zeng, X.B., Hu, Q.X., 2007. Utilization efficiency of chemical fertilizers among different counties in China. Acta Geogr. Sin. 57, 531-538.

Chen, Y., Li, X., Wang, J., 2011. Changes and effecting factors of grain production in China. Chinese Geogr. Sci. 21, 676-684.

Chien, S.H., Prochnow, L.I., Tu, S., 2011. Agronomic and environmental aspects of phosphate fertilizers varying in source and solubility: an update review. Nutr. Cycl. Agroecosys. 89, 229-255.

Deng, J., 1989. Introduction to grey system. J. Grey Syst. 1, 1-4.

Du, J.J., Wang, X.A., Liao, Z.W., Tian, J.L., Chen, J.H., 2005. Effects of different extract conditions on water dissolution rate of coated controlled/slowed release fertilizer. Plant Nutr. Fert. Sci. 11, 71-78.

Fang, Y., Feng, Z., Hu, Y., 2007. Balance of field nitrogen nutrient input/output using GIS technology in China. T. CSAE 23, 35-41.

Feng, Z., Fang, Y., 2006. Analysis on nitrogen input/output balance in croplands on county level in Gansu province. Agr. Res. Arid Area. 24, 152-158.

Fu, Q., Yin, C.Q., Shan, B.Q., 2006. Phosphorus sorption capacities in a headstream landscape - the pond chain structure. J. Envir. Sci. Chin. 18, 1004-1011.

Gao, F.J., Lü, J.L., 2006. Effect of urease deeply applied on wheat yield and fertilizer use efficiency. Shandong Agric. Sci. 6, 49-50.

Gao, X.Z., Ma, W.Q., Du, S., Zhang, F.S., Mao, D.R., 2001. Current status and problems of fertilization in China. Chin. J. Soil Sci. 32, 258-261.

Guan, W., Sun, M., Lu, Y., 2011. Changes of regional environment quality pattern in China since 1986-2008. J Environ. Sci. Chin. 32, 609-618.

Han, H., Bosch, N., Allan, J.D., 2011. Spatial and temporal variation in phosphorus budgets for 24 watersheds in the Lake Erie and Lake Michigan basins. Biogeochemistry 102, 45-58.

He, F., Huang, J.L., Cui, K.H., Zeng, J.M., Xu, B., Peng, S.B., Buresh, R.J., 2007. Effect of real time and site specific nitrogen managements on rice yield and quality. Sci. Agri. Sin. 40, 123-132.

Hu, L.J., Li, T.L., 2005. Questions and countermeasures in the development of precision agriculture. J. Shenyang Agri. Univ. 7, 400-402.

Hu, S.H., Zhou, Q.H., Gao, Y.N., 2011a. Annual variation of nitrogen, phosphorus and silica levels, and their effects on phytoplankton distribution (diatoms and cyanobacteria) and eutrophication of small shallow lakes. Fresen. Environ. Bull. 20, 2824-2833.

Hu, Z., Yuan, J., Hu, Z., 2011b. Study on China's low carbon development in an economy- energy- electricity-environment framework. Energy Policy 39, 25962605.

Huang, J., Wang, X., Zhi, H., 2011. Subsidies and distortions in China's agriculture: evidence from producer-level data. Aust. J. Agr. Resour. Econ. 55, 53-71.

Istvanovics, V., Somlyody, L., Clement, A., 2002. Cyanobacteria-mediated internal eutrophication in shallow Lake Balaton after load reduction. Water Res. 36, 3314-3322.

Jess, L.D., 2004. In: Precision Agriculture. A bird's eye view of precision agriculture. Ed. Wageningen Academic Press, Wageningen.

Jordan, T.E., Weller, D.E., 1996. Human contributions to terrestrial nitrogen flux. Bioscience 46, 655-664.
Kelderman, P., Koech, D.K., Gumbo, B., 2009. Phosphorus budget in the low-income, peri-urban area of Kibera in Nairobi (Kenya). Water Sci. Technol. 60, 26692676.

Kerr, J.G., Burford, M.A., Olley, J.M., 2011. Examining the link between terrestrial and aquatic phosphorus speciation in a subtropical catchment: the role of selective erosion and transport of fine sediments during storm events. Water Res. 45 3331-3340.

Kronvang, B., Audet, J., Baattrup, P.A., 2012. Phosphorus load to surface water from bank erosion in a Danish Lowland River basin. J. Environ. Qual. 41, 304-313.

Leeben, A., To nno, R., Freiberg, V., 2008. History of anthropogenically mediated eutrophication of Lake Peipsi as revealed by the stratigraphy of fossil pigments and molecular size fractions of pore-water dissolved organic matter. Hydrobiologia 599, 49-58.

Li, J., 2007. Animal nutrition and feed, Ed.. Chongqing University Press, Chongqing, China.

Li, Q.K., Zhu, Z.L., Yu, T.R., 1998. Fertilizer questions in sustainable development of agriculture in China, Ed.. Jiangxi Science and Technology Press, Nanchang China.

Li, X., Yu, Z., Song, X., 2011. Nitrogen and phosphorus budgets of the Changjiang River estuary. Chin. J. Oceanol. Limnol. 29, 762-774.

Liang, C.H., 1999. Common Fertilizers and Their Application Techniques. Shengyang Press, Shengyang, China.

Lin, C.L., 2004. Use of the Taguchi method and grey relational analysis to optimize turning operations with multiple performance characteristics. Mater. Manuf. Process. 19, 209-220.

Liu, L.J., Xu, W., Sang, D.Z., Liu, C.L., Zhou, J.L., Yang, J.C., 2006. Site specific nitrogen management increases fertilizer nitrogen use efficiency in rice. Acta Agro. Sin. 32, 987-994.

Liu, S.M., Zhu, B.D., Zhang, J., 2010. Environmental change in Jiaozhou Bay recorded by nutrient components in sediments. Mar. Pollut. Bull. 60, 1591-1599.

Lowrance, R.R., Leonard, R.A., Asmussen, L.E., 1985. Nutrient budgets for agricultural watersheds in the southeastern coastal plain. Ecology 66, 287-296.

Lu, X.L., Wu, Q.Z., 2004. Extension of intellectualization precision fertilization in Guangxi. Chin. Agri. Tech. Exten. 1, 6-7.

McIsaac, G.F., David, M.B., Gertner, G.Z., 2001. Nitrate flux in the Mississippi River. Nature 414, 166-167.

Neset, T.S.S., Bader, H.P., Scheidegger, R., 2008. The flow of phosphorus in food production and consumption - Linkoping, Sweden, 1870-2000. Sci. Total Environ. 396, 111-120.

Obour, A.K., Silveira, M.L., Vendramini, J.M.B., 2011. A phosphorus budget for bahiagrass pastures growing on a typical florida spodosol. Agron. J. 103, 611616.

OECD, 2001. OECD National Soil Surface Nutrient Balances Explanatory Notes. Ed. OECD Secretary, Paris.

Peng, S.B., Garcia, F.V., Laza, R.C., Sanico, A.L., Visperas, R.M., Cassman, K.G., 1996 Increased N-use efficiency using a chlorophyll meter on high yielding irrigated rice. Field Crop. Res. 47, 243-252.

Peng, S.B., Huang, J.L., Zhong, X.H., Yang, J.C., Wang, G.H., Zou, Y.B., Zhang, F.S., Zhu, Q.S., Bureshl, R., Wittl, C., 2002. Research strategy in improving fertilize nitrogen use efficiency of irrigated rice in China. Sci. Agri. Sin. 35, 1095-1103.

Rivera, E.C., Queiroz, J.F., Ferraz, J.M., 2007. Systems models to evaluate eutrophication in the Broa Reservoir, Sao Carlos. Brazil. Ecol. Model. 202, 518-526.

Russell, M.J., Weller, D.E., Jordan, T.E., 2008. Net anthropogenic phosphorus inputs: spatial and temporal variability in the Chesapeake Bay region. Biogeochemistry $88,285-304$.

Schroder, J.J., Smit, A.L., Cordell, D., 2011. Improved phosphorus use efficiency in agriculture: a key requirement for its sustainable use. Chemosphere 84,822 831.

Shang, X.J., 2009. Study on Plant Species Selection and Wastewater Purification Efficiency in Constructed Wetlands in Beijing. Master thesis. Chinese Academy of Forestry, Beijing, Beijing, p. 21.

Stevens, C.J., Quinton, J.N., Bailey, A.P., 2009. The effects of minimal tillage, contour cultivation and in-field vegetative barriers on soil erosion and phosphorus loss. Soil Till. Res. 106, 145-151.

Straalen, N.M., Gestel, C.A.M., 2008. A stress ecology framework for comprehensive risk assessment of diffuse pollution. Sci. Total Environ. 406, 479-483.

Tugrul, S., Uysal, Z., Erdogan, E., 2011. Changes of eutrofication indicator parameters (TP, DIN, Chl-a and TRIX) in the cilician basin (Northeast Mediterranean). Ekoloji 20, 33-41.

Van, H.H.H., 1998. Factors Affecting Manure Quantity, Quality, and Use. Ed. Texas Animal Nutrition Council, Texas, USA

Wang, X.B., Dai, K., Wang, Y., 2010. Nutrient management adaptation for dryland maize yields and water use efficiency to long-term rainfall variability in China. Agr. Water Manage. 97, 1344-1350.

Wang, Y.F., 2002. Study on applying effect of hydroquinone in corn. Corn Sci. 10, 90 92.

Wang, Y.G., 2003. The brief introduction of the progress of food composition table in China. Acta Nutr. Sin. 25, 126-129.

Wu, Q., Zhou, W., Zhang, L., 2011. China's environment: challenges and solutions. Environ. Earth Sci. 64, 1503-1504.

Wu, S.X., 2005. The Spatial and Temporal Change of Nitrogen and Phosphorus Produced by Livestock and Poultry and their Effects on Agricultural Non-poin Pollution in China. PhD thesis. The Chinese Academy of Agricultural Science, Beijing, Beijing, p. 56-58.

Xiong, S., Zhang, S.D., 2007. Evaluation of land application of sewage sludge in Beijing. J. Hebei Inst. Archit. Civil Eng. 25, 36-39. 
Yan, X., Jin, J.Y., He, P., Liang, M.Z., 2008. Recent advances in technology of increasing fertilizer use efficiency. Sci. Agri. Sin. 41, 450-459.

Yu, G.H., Zhang, Y.Z., 2006. Yield and nutrition qualities of pakchoi as affected by three types of nitrification inhibitors. Chin. J. Soil Sci. 37, 737-740.

Zhai, J.H., Gao, Y.J., Zhou, J.B., 2002. The review of controlled/slow release fertilizer. Agri. Res Arid Area. 20, 45-48.

Zhang, W., 2010. Study on Estating Models for Estimation of Per Capita Domestic Wastewater Discharge. $\mathrm{PhD}$ thesis. Suzhou University of Science and Technology, Suzhou, Jiangsu, p. 2-3.
Zhou, D., An, P., Pan, Z., 2012. Arable land use intensity change in China from 1985 to 2005: evidence from integrated cropping systems and agro economic analysis. J. Agr. Sci. 150, 179-190.

Zhou, W.J., 2010. Water resources and water investigation report in china. China Prices 3, 19-23. 